\title{
Perbaikan Penampilan Produksi Ayam Pedaging dengan Penambahan Ekstraksi Temulawak Pelarut Ethanol
}

\section{Improvement of Broiler Production Performance with Addition Turmeric Extraction Solvent Ethanol}

\author{
Agung Adi Candra, Dwi Desmiyeni Putri dan Zairiful \\ Jurusan Peternakan Politeknik Negeri Lampung \\ Jln. Soekarno Hatta No 10 Rajabasa Bandar Lampung \\ Email: adicandra@polinela.ac.id
}

\begin{abstract}
Broiler is been developed anymal as a source of animal protein needs. Various feed additif given to broiler to spur additional growth as well as feed and medicine. One of the diseases that are immunosuppressed chickens is coccidiosis. Chickens infected with coccidiosis will show symptoms of diarrhea, emaciation and intestinal damage simultaneously, thus reducing the rate of growth in chickens. With the ability of antidiarrhea and anti-inflammatory turmeric is expected to be an alternative for the treatment and prevention of coccidiosis in particular and general gastrointestinal disease in chickens. The purpose of this study was to determine the activity of ginger are extracted with solvent water to the broiler performance infected by Eimeria maxima. The results showed that administration of turmeric extraction with ethanol can increase body weight gain, feed efficiency and lower feed conversion value is better than giving solvent extraction of turmeric with water. turmeric extraction with ethanol was not effect to blood diferentiation but decrease level of total cholesterol, trigliserida, $H D L$, dan $L D L$ on serum
\end{abstract}

Keywords: performance, broiler, Eimeria maxima, turmeric

Diterima: 28-11-2013, disetujui:17-01-2014

\section{PENDAHULUAN}

Broiler adalah ayam tipe pedaging yang paling umum diternakkan di Indonesia. Penampilan broiler yang mampu berproduksi optimal di daerah tropis membuat ayam jenis ini menjadi primadona dalam peternakan unggas di Indonesia. Berbagain upaya dilakukan peternak lakukan untuk meningkatkan penampilan produksi ayam broiler, dari modifikasi tata laksanan pemeliharaan, pakan, hingga penambahan feed additive.

Perkembangan broiler yang tinggi itu secara umum sangat dipengaruhi oleh perbaikan ekonomi masyarakat sehingga tingkat konsumsi daging meningkat. Peningkatan pola konsumsi ini belum dapat diimbangi oleh peningkatan produksi ayam pedaging di Indonesia. Peternak banyak yang terpaksa harus menutup usahanya karena harga saran produksi peternakan (sapronak) yang 

Agung Adi Candra, Dwi Desmiyeni Putri dan Zairiful: Perbaikan Penampilan Produksi Ayam Pedaging...

melambung tinggi (terutama pakan) sehingga kebutuhan daging belum dapat tercukupi. Hal ini menjadi tantangan peternak untuk meningkatkan produksi unggas untuk mencukupi kebutuhan daging. Ayam broiler (ayam pedaging) dikembangkan sebagai sumber pemenuhan kebutuhan protein hewani. Ayam broiler merupakan ternak ayam yang paling cepat pertumbuhannya, hal ini karena ayam broiler merupakan hasil budidaya yang menggunakan teknologi maju, sehingga memiliki sifat- sifat ekonomi

yang menguntungka yang memiliki karakteristik ekonomis, dengan ciri khas pertumbuhan cepat sebagai penghasil daging, konversi pakan irit, siap dipotong pada usia relatif muda, serta menghasilkan daging berkualitas serat lunak (Murtidjo, 1987).

Laju pertumbuhan yang cepat pada ayam pedaging selalu diikuti perlemakan yang cepat, dimana penimbunan lemak yang cenderung meningkat sejalan dengan meningkatnya bobot badan. Pertumbuhan yang cepat pada ayam pedaging yang sering diikuti pelemakan yang tinggi, keadaan ini menjadi masalah bagi konsumen yang menginginkan daging ayam dengan perlemakan yang rendah.

Temulawak berdasarkan rimpang kering dengan kadar air adalah Pati 58,24; Lemak (fixed oil)12,10; Kurkumin 1,55; Serat Kasar 4,20; Abu 4,90; Protein 2,90; Mineral 4,2; dan Minyak Atsiri 4,9. Menurut Sinambela (1985), komposisi rimpang kimia temulawak dapat dibagi menjadi dua fraksi yaitu zat warna dan minyak Atsiri Warna kuning pada temulawak disebabkan oleh adanya kurkuminoid $\left(\mathrm{C}_{21} \mathrm{H}_{20} \mathrm{O}_{6}\right)$. Fraksi kurkuminoid rimpang temulawak terdiri dari dua macam yaitu kurkumin dan desmetoksikurkumin. Secara kimia, kurkuminoid pada temulawak merupakan turunan dari diferuloilmetan, yaitu dimetoksidiferuloil metan (kurkumin) dan desmetoksikurkumin.

Koksidiosis adalah penyakit parasiter yang umum menyerang ayam. Kejadian kosidiosis umum terjadi di daerah tropis dan menimbulkan penurunan kekebalan tubuh.imunosupresif. Ayam yang terinfeksi koksidiosis aka menunjukkan gejala diare, kekurusan dan kerusakan usus secara simultan sehingga menekan laju pertumbuhan ayam. Dengan kemampuan anti diare dan anti inflamasi ini diharapkan temulawak dapat menjadi alternatif bagi pengobatan dan pencegahan coccidiosis secara khusus dan penyakit gastrointestinal secara umum pada ayam.

Salah satu alternatif pilihan yang dapat dilakukan sebagai terobosan dalam pencegahan penyakit koksidiosis adalah dengan pemberian temulawak (Curcuma Xanthorrhiza Roxb). Penggunaan temulawak sebagai pengobatan telah banyak dilaporkan, diantaranya adalah sebagai antibakteri, menurunkan kadar kolesterol, menghilangkan nyeri, anti radang, dan menurunkan panas serta menghaluskan kulit. Selain itu, juga bermanfaat mencegah penyakit lever dan melancarkan air seni, mengurangi gangguan penyakit hepatitis, batu empedu, sakit maag, ginjal, asma, bisul, kolesterol, eksem, menambah nafsu makan, bau badan, sembelit, memperbanyak ASI, sariawan, menghilangkan nyeri haid, dan batuk, anti diare, dan anti inflamasi.

Tujuan dari penelitian ini adalah mengetahui aktivitas temulawak yang diektraksi deng pelarut air terhadap penampilan ayam pedaging yang diinfeksi Eimeri maxima.

\section{METODE}

Penelitian ini dilaksanakan di Laboratorium ternak dan kandang percobaan Politeknik Negeri Lampung dari Maret - Agustus 2013.

Peralatan yang digunakan dalam penelitian ini adalah kandang ayam, sekam, sekat, feeder, drinker, brooder, nomor ayam, spuit, mikroskop, timbangan, gelas ukur, gelas objek, Mc Master counting slide, alat untuk pembuatan preparat histologi dan counter. 
Bahan yang digunakan antara lain; ayam broiler, ransum ayam, air minum, koksidostat, ekstrak temulawak dengan pelarut air dan etanol. Cara pembuatan ekstrak adalah dengan membuat simplisia temulawak kemudian dihaluskan menjadi mesh dan dimaserasi dengan pelarut air dan etanol. Kemudian masing-masing pelarut dikentalkan dengan menggunakan rotary evaporator.

Enam puluh ekor Day Old Chick (DOC) jenis kelamin jantan, ditempatkan dalam kandang kelompok berukuran $4 \times 2$ meter dibagi dalam 12 petak, ukuran tiap petak $100 \times 50 \times 60 \mathrm{~cm}$, dan 5 ekor DOC per petak, dilengkapi tempat makan, tempat minum dan lampu pijar 25 watt masing-masing 1 buah. Vaksin ND B1 umur 4 hari melalui tetes mata dan vaksin ND lasota umur 21 hari melalui injeksi intramusculer. Broiler dipelihara dua tahap yaitu tahap pertama broiler diberikan butiran pada umur 1-14 hari. Pada hari ke 14 semua ayam diinfeksi dengan Eimeria maxima. Tahap kedua broiler diberikan perlakuan berupa ekstrak temulawak pelarut air (P1) dan ekstrak temulawak pelarut etanol (P2) dan kontrol dengan blanko pada hari ke15 - 35.

Parameter yang diukur adalah konsumsi pakan, pertambahan berat badan, persentase berat karkas, efisiensi ransum dan konversi pakan. Data dianalisis dengan Rancangan Acak Lengkap dan perlakuan yang berpengaruh nyata terhadap parameter yang diukur diuji dengan uji BNT

\section{HASIL DAN PEMBAHASAN}

\section{Penampilan Produksi}

Penampilan produksi pada ternak ayam broiler secara umum dilihat dari indikator konsumsi, pertambahan bobot badan, konversi ransum, dan efisiensi ransum. Dari hasil penelitian didapatkan bahwa dengan penambahan ekstraksi temulawak dengan pelarut etanol memberikan tingkat penggunaan ransum paling baik dengan konsumsi $5.565 \mathrm{~g}$ dan pertambahan bobot badan $1.693 \mathrm{~g}$. Kondisi ini lebih baik jika dibandingkan penampilan ayam yang diberikan temjlawak ekstrak air dan tanpa temulawak yang menghasilkan berturut-turut pertambahan bobot badan $1.4201 .531 \mathrm{~g}$. Pertambahan bobot badan yang paling baik diantara kelompok perlakuan juga diikuti konversi ransum yang secara berurut menunjukkan bahwa temulawak ekstrak etanol lebih baik jika dibandingkan temjlawak ekstrak air dan kontrol, berurutan nilai konversi ransum adalah 3,34; 4,35; dan 3,97. Dari pengamatan yang dilakukan, didapatkan hasil sebagai berikut

Tabel 1. Konsumsi, pertambahan bobot badan, konversi ransum, efisiensi ransum dan volume empedu ayam broiler yang dipelihara dengan penambahan temulawak esktraksi air dan etanol

\begin{tabular}{|c|c|c|c|}
\hline \multirow{2}{*}{ Parameter } & \multicolumn{3}{|c|}{ Perlakuan } \\
\hline & Tanpa temulawak & Temulawak ekstrak air & Temulawak ekstrak etanol \\
\hline Konsumsi (g) & $6.087 \pm 148,2$ & $6.178 \pm 146$ & $5.656 \pm 146,9$ \\
\hline $\begin{array}{l}\text { Pertambahan bobot } \\
\text { badan }(\mathrm{g})\end{array}$ & $1.531,75 \pm 350,8$ & $1.420,75 \pm 315,1$ & $1.693,25 \pm 367,7$ \\
\hline Konversi ransum & 3,97 & 4,35 & 3,34 \\
\hline Efisiensi ransum (\%) & 25 & 23 & 30 \\
\hline Volume empedu & 0,5 & 0,475 & 0,9 \\
\hline
\end{tabular}

Dari hasil penelitian pemberian temulawak yang diekstraksi dengan air dan etnaol tidak memberikan perbedaan nyata dalam pertambangan bobot badan. Kecenderungan hasil menunjukkan bahwa pemberian temulawak yang diekstrak dengan etanol memberikan aktivitas lebih baik dibandingkan diekstrak dengan air. Menurut Yuniusta et al. (2007) kunyit membantu proses 
Agung Adi Candra, Dwi Desmiyeni Putri dan Zairiful: Perbaikan Penampilan Produksi Ayam Pedaging...

metabolisme enzimatis pada tubuh ayam karena ada kandungan senyawa kurkuminoid dan minyak atsiri.

Dari data konsumsi didapatkan bahwa secara deskriptif, pemberian temulawak yang diekstrak dengan air memberikan jumlah konsumsi yang paling tinggi yaitu $6.178 \mathrm{~g} / 35$ hari pemeliharaan dibandingkan dengan temulawak yang diektraksi dengan etanol hanya sebesar $5.656 \mathrm{~g} / 35$ hari pemeliharaan.

Konversi ransum ayam yang diberikan temulawak yang diekstraksi dengan etanol menunjukkan nilai 3,34 artinya un tuk menghasilkan $1 \mathrm{~kg}$ daging membutuhkan ransum sebanyak 3,34 $\mathrm{kg}$. Hal ini lebih rendah bila dibandingkan dengan pemberian temulawak ekstrasi ar yaitu sebesar 4,35 dan kontrol sebesar 3,97. Hal ini menunjukkan bahwa temulawak ekstraksi etanol memberikan efek terbaik dalam penggunaan ransum. Hal senada nampak pada nilai efisiensi penggunaan ransum, paling rendah temulawak ekstraksi air (23\%) diikuti kontrol (25\%) dan tertinggi temulawak ekstraksi etanol sebesar $30 \%$. Artinya dengan penambahan temulawak yang diektraksi etanol mampu memperbaiki efisiensi ransum ayam dalam kondisi imunosupresi akibat infeksi Eimeria maxima. Hal ini dapat menjadi solusi bagi terapi pada ayam yang sedang mengalami cekaman/stress.

Darwis et al. (1991). Mengatakan bahwa zat kurkuminoid mempunyai khasiat anti bakteri dan dapat merangsang dinding kantung empedu untuk mengeluarkan cairan empedu sehingga dapat memperlancar metabolisme lemak. Cairan empedu adalah suatu cairan garam berwarna kuning kehijauan yang mengandung kolesterol, fosfolifid, lesitin serta pigmen empedu. Empedu mengandung sejumlah garam hasil dari percampuran antara Natrium dan Kalium dengan asam-asam empedu (asam glikokolat dan taurokolat). Garam-garam ini akan bercampur dengan lemak di dalam usus halus untuk membentuk misel, jika misel sudah terbentuk akan menurunkan tegangan antar permukaan lemak dan gerakan mencampur pada saluran pencernaan berangsur-angsur dapat memecah globulus lemak menjadi partikel yang lebih halus sehingga lemak dapat dicerna.

Kerja temulawak dalam meningkatkan bobot badan ayam pedaging salah satunya disebabkan oleh kerja temulawak yang bersifat kolagoga. Hal ini ditunjukkan dengan volume empedu yang meningkat pada ekstraksi temulawak dengan etanol (tabel 1) sedangkan pemberian temulawak ekstraksi air tidak berbeda jika dibandingkan dengan kontrol. Frandson (1992) menyatakan garamgaram empedu yang merupakan garam-garam basa dapat membantu juga dalam menciptakan suasana yang lebih alkalis dalam chyme intestinal. Garam empedu menetralisir keasaman isi usus di daerah lekukan duodenum, menghasilkan keadaan yang alkalis sehingga dapat mencapai tingkat $\mathrm{pH}$, volume, ataupun tingkat kecernaan yang

sesuai.

Minyak atsiri yang terkandung dalam kunyit berkhasiat untuk mengatur keluarnya asam lambung agar tidak berlebihan dan mengurangi pekerjaan usus yang terlalu berat dalampencernaan zat-zat makanan (Darwis et al., 1991). Glandula fundika adalah kelenjar lambung yang mengandung selsel khusus yaitu sel-sel body chief sebagai zimogen tidak aktif, yaitu pepsinogen yang diaktifkan menjadi pepsin oleh $\mathrm{HCl}$ yang disekresi oleh sel-sel parietal. Pepsin ini melakukan pemecahan protein menjadi asam amino.

Pepsin juga menimbulkan efek autokatalitik yaitu sejumlah kecil pepsin dapat menyebabkan pengaktifan pepsinogen yang masih tersisa, yang berarti juga semakin banyak pepsin yang terbentuk sehingga menyebabkan pemecahan protein yang semakin baik (Harper et al., 1980). Pemecahan protein yang semakin baik akan menyebabkan metabolisme protein dalam tubuh semakin baik yang akan berpengaruh juga pada pertumbuhan. 
Minyak atsiri yang mengontrol asam lambung agar tidak berlebihan dan tidak kekurangan menyebabkan isi lambung tidak terlalu asam, sehingga apabila isi lambung tersebut masuk ke duodenum untuk menurunkan keasaman chyme semakin cepat dalam mengubahnya ke keadaan $\mathrm{pH}$ yang sesuai untuk diteruskan ke usus halusuntuk diserap (Darwis et al., 1991).

Pengaturan sekresi $\mathrm{HCl}$ dan pepsin yang semakin lancar akan menyebabkan pencernaan dan penyerapan zat-zat makanan semakin lancar, dengan demikian akan menyebabkan peningkatan kekosongan pada lambung yang akan berpengaruh pada konsumsi dan pertumbuhan.Seperti yang dikatakan oleh Frandson (1992) bahwa faktor-faktor yang mengontrol pengosongan lambung melalui sphincter pilorik, mencakup volume makanan di dalam perut,fluiditas campuran, serta reseptivitas duodenum.

\section{Penampilan Fisiologis Darah}

Gambaran fisiologis ayam broiler dilihat dari gambaran umum darah akibat pemberian temulawak baik yang diberikan ekstrak temulawak dengan pelarut air, etanol maupun tanpa pemberian temulawak sebagaimana disajikan dalam tabel 2.

Tabel 2. Gambaran darah pemberian temulawak ekstrak temulawak air dan etanol

\begin{tabular}{lccc}
\hline Gambaran darah & kontrol & Temulawak ekstrak air & Temulawak ekstrak etanol \\
\hline Eritrosit & 2,43 & 2,38 & 2,845 \\
Haemoglobin & 9,5 & 8,8 & 9,2 \\
Trombosit & 46 & 46,5 & 58,5 \\
Heterofil & 27,5 & 27,5 & 27,5 \\
\hline
\end{tabular}

Gambaran darah menunjukkan bahwa tidak terdapat perbedaan antara kelompok perlakuan temulawak ektrak etanol, air, dan kontrol. Hal ini menunjukkan bahwa penambahan temulawak tidak berpengaruh terhadap kondisi gambaran fisiologis darah serta tidak mernginduksi adanya reaksi penolakan dari tubuh.

Untuk mengetahui kemampuan temulawak ekstrak air dan etanol dalam menurunkan kadar kolesterol darah, maka dilakukan pengujian terhadap kadar kolesterol total, trigliserida, HDL, dan LDL. Gambaran serologis terhadap kandungan kolesterol darah akibat pemberian temulawak disajikan dalam tabel 3.

Tabel 3. Gambaran serologis darah temulawak ektrak air dan ekstrak etanol.

\begin{tabular}{lccc}
\hline \multicolumn{1}{c}{ Gambaran darah } & kontrol & Temulawak ekstrak air & Temulawak ekstrak etanol \\
\hline Kolesterol total & 92,5 & 86 & 60,5 \\
Trigliserida & 114,5 & 96,5 & 59,5 \\
HDL & 74 & 70 & 60,5 \\
LDL & 14,5 & 15 & 11,5 \\
\hline
\end{tabular}

Dari gambaran serologis, didapatkan bahwa temulawak ekstrak etanol mampu menurunkan kadar kolesterol dengan nilai terendah 60,5 dibandingkan temulawak ekstraksi 
Agung Adi Candra, Dwi Desmiyeni Putri dan Zairiful: Perbaikan Penampilan Produksi Ayam Pedaging...

air dan kontrol, demikian pula untuk kandunga trigliserida dan HDl, namun untuk nilai LDL nilai temualawak ektrak air lebih kecil daripada temulawak etanol

\section{KESIMPULAN}

Pemberian ekstraksi temulawak dengan etanol mampu meningkatkan pertambahan bobot badan, efisiensi ransum dan menurunkan nilai konversi ransum lebih baik dibandingkan pemberian ekstraksi temulawak dengan pelarut air. Pemberian ekstraksi temulawak dengan etanol tidak mempengaruhi gambaran fisiologis darah namun dapat menurunkan kadar kadar kolesterol total, trigliserida, HDL, dan LDL pada serum darah

\section{DAFTAR PUSTAKA}

Darwis, S. N., A. B. D. Modjo Indo dan S. Hasiyah. 1991. Tanaman Obat Familia Zingiberaceae. Badan Penelitian dan Pengembangan Pertanian Industri. Bogor.

Sinambela JM. 1985. Fitoterapi. Fitostandar, dan Temulawak. Di dalam: Proseding Simposium Nasional Temulawak . Lembaga Penelitian Universitas Padjajaran. Bandung.

Frandson, R. D. 1992. Anatomi dan Fisiologi. Alih Bahasa Bambang Srigandono dan Koen Praseno. Edisi keempat. Gadjah Mada University Press. Yogyakarta.

Harper, A. H., V. W Rodwell and P. A Mayer. 1980. Biokimia (Review of Physiological Chemistry). Alih Bahasa Martin Muliawan. Edisi ke-17. Penerbit Buku KedokteranE. G. C. Jakarta.

Murtidjo, B. A. 1987. Pedoman Beternak Ayam Broiler. Penerbit Kanisius. Yogyakarta.

Yuniusta, Syahrio T., D. Septinova. 2007. Perbandingan Performa Antara Broiler Yang Diberi Kunyit dan Temulawak melalui Air minum. Fak. Pertanian. Univ. Lampung. 